JIPSINDO No. 1, Volume 2, Maret 2015

\title{
UPAYA MENINGKATKAN HASIL BELAJAR IPS MATERI VULKANISME MELALUI MEDIA MAKET BUBUR KERTAS SISWA KELAS VII A SMPN 2 NGEMPLAK SEMESTER 1 TAHUN PELAJARAN 2013/2014
}

\author{
Tri Worosetyaningsih \\ SMPN 2 Ngemplak, Sleman \\ Email: triworosetyaningsih@yahoo.co.id, Hp : 08122700632
}

\begin{abstract}
Abstrak
Penelitian ini bertujuan untuk meningkatkan hasil belajar IPS materi Vulkanisme melalui media maket bubur kertas siswa kelas VII A SMP Negeri 2 Ngemplak Semester 1 tahun pelajaran 2013/2014. Penelitian ini merupakan penelitian tindakan kelas (Classroom Action Research) yang mencakup perencanaan, pelaksanaan, observasi, dan refleksi. Penelitian ini berlangsung 3 siklus. Sumber data dari penelitian ini adalah siswa kelas VII A SMP Negeri Ngemplak yang berjumlah 31 siswa. Metode pengumpulan data menggunakan observasi, evaluasi/tes, dokumentasi, dan catatan lapangan. Metode analisis data yang digunakan yaitu metode analisis data deskriptif kuantitatif untuk menggambarkan hasil belajar. Hasil penelitian dapat disimpulkan sebagai berikut: Media maket bubur kertas dapat meningkatkan hasil belajar IPS materi Vulkanisme siswa kelas VII A SMPN 2 Ngemplak Semester 1 tahun pelajaran 2013/2014. Hal ini dapat dibuktikan dari analisis hasil belajar siswa yang dilaksanakan menunjukkan adanya peningkatan, pada prasiklus hasil rata-rata persentase kentuntasan belajar sebesar 25.8\%, siklus I persentase ketuntasan belajar dari $6,5 \%$ pada pre-tes menjadi $19,4 \%$ pada postes dengan kategori kurang, jadi mengalami peningkatan $12,9 \%$. Pada siklus II persentase ketuntasan belajar dari $45 \%$ dengan kategori kurang menjadi $71 \%$ dengan kategori baik jadi meningkat $26 \%$ sedangkan siklus III dari $80,6 \%$ pada pretes dengan kategori baik menjadi 90\% dengan kategori baik sekali jadi mengalami peningkatan sebesar 9,4\% . Hasil tersebut sudah sesuai dengan kriteria ketuntasan yang diharapkan bahkan melebihi target sebesar 85\%. Hal ini menunjukkan pembelajaran IPS pada materi Vulkanisme melalui media maket bubur kertas dapat meningkatkan hasil belajar.
\end{abstract}

Kata Kunci: hasil belajar IPS, materi vulkanisme, media maket bubur kertas 


\begin{abstract}
This study aims to improve learning outcomes IPS Volcanism material through mock media pulp A seventh grade students of SMP $N 2$ Ngemplak Semester 1 2013/2014 lesson. This research is a class action (Classroom Action Research) that includes planning, implementation, observation, and reflection. Research lasted 3 cycles. Sources of data from this study were students of class VII A SMP Ngemplak is 31 students. Methods of data collection use observation, evaluation, documentation, and field notes. Data analysis method used is descriptive quantitative methods of data analysis to describe learning outcomes. The results research can be summarized as follows: Media mockups pulp can improve the results of social studies class VII Volcanism material A SMP 2 Ngemplak Semester 1 2013/2014 school year. This is evident from the analysis of student learning outcomes conducted showed an increase, the average yield cycles completed learning percentage of $25.8 \%$, the first cycle of learning completeness percentage of $6.5 \%$ on the pretest to $19.4 \%$ in post-test with less category, so an increase of $12.9 \%$. In the second cycle learning completeness percentage of $45 \%$ with less to $71 \%$ with both categories be increased by $26 \%$ while the third cycle of $80.6 \%$ on the pretest with a good category to $90 \%$ in both categories once be increased by 9.4\%. These results are in accordance with the expected completeness criteria even exceeding the target of $85 \%$. The shows the IPS learning materials through media Volcanism mockups pulp can improve learning outcomes.
\end{abstract}

Keywords: learning outcomes IPS, content volcanism, mockups pulp.

\title{
Pendahuluan
}

Kurikulum mempersiapkan peserta didik dalam menghadapi tantangan-tantangan di masa depan melalui pengetahuan, keterampilan, sikap, dan keahlian untuk beradaptasi serta bisa bertahan hidup dalam lingkungan yang senantiasa berubah. Kurikulum sebagai salah satu substansi pendidikan perlu didesentralisasikan terutama dalam pengembangan silabus dan pelaksanaannya disesuaikan dengan tuntutan kebutuhan siswa, keadaan sekolah, dan kondisi sekolah atau daerah. Dengan demikian, sekolah atau daerah memiliki cukup kewenangan untuk merancang dan menentukan materi 
pokok, kegiatan pembelajaran, dan hasil penilaian hasil pembelajaran tetapi tidak boleh lepas dari Standar Isi dan Standar Kompetensi lulusan.

Dalam pelaksanaan kurikulum kita tidak hanya mempertimbangkan apa yang harus diajarkan, bagaimana cara mengajarkannya, akan tetapi juga tujuan yang akan dicapai dan faktor anak itu sendiri, khususnya minat anak untuk mengikuti pelajaran.

Mata pelajaran IPS bertujuan mengembangkan potensi peserta didik agar peka terhadap masalah sosial yang terjadi di masyarakat, memiliki sikap mental positif terhaap perbaikan segala ketimpangan yang terjadi, dan terampil mengatasi setiap masalah yang terjadi sehari-hari baik menimpa dirinya sendiri maupun yang menimpa kehidupan masyarakat (Nursid Sumaatmaja dalam Endang Ekowati, 2011: 1). Untuk membangun generasi muda yang peka terhadap maslah sosial dalam kehidupannya perlu program pendidikan yang tidak hanya membekali sekedar pengetahuan secara keilmuan, tetapi juga pemaknaan dan aplikasinya atas pengetahuan yang diperoleh dalam kehidupan sehari-hari (Rudy Gunawan, 2011: 3).

Dengan demikian sebagai bagian integral dari kurikulum sekolah, mata pelajaran IPS memerlukan guru-guru yang memiliki peran strategis untuk mempersiapkan peserta didik menjadi manusia Indonesia yang cerdas, antara lain cerdas spiritual, emosional, sosial, intelektual, maupun kinestetis. Selain itu, dapat sebagai motor penggerak perubahan di dunia pendidikan. Perubahan-perubahan yang dilakukan oleh guru dimaksudkan untuk mengantarkan peserta didik menjadi anak yang kompetitif, berkepribadian unggul, berprestasi, bersemangat juang tinggi, mandiri, pantang menyerah, pembangun dan pembina jejaring, 
bersahabat dengan perubahan, produktif, sadar mutu, berorientasi global, pembelajar sepanjang hayat serta inovatif, dan menjadi agen perubahan. Untuk itu guru harus harus menjalankan profesinya secara professional sesuai UU Nomor 14 Tahun 2005 tentang Guru dan Dosen Pasal 14, dengan cara selalu melakukan kreativitas dan inovasi dalam mengajar, mampu melaksanakan pembelajaran yang efektif, dalam arti menguasai materi, mampu memilih permasalahan yang layak diangkat sebagai bahan belajar, serta mengembangkan strategi pembelajaran yang mampu mengoptimalkan pencapaian kompetensi.

Mata Pelajaran IPS di SMP termasuk mata pelajaran yang kurang diminati siswa dikarenakan selain materi yang banyak, terdiri dari multidisiplin dan kurangnya media pembelajaran yang menarik. Belajar menjadi kegiatan yang semakin membosankan, statis, stressful, anak-anak kuyu, mengantuk, bosan, dan malas. Belajar pada era teknologi saat ini bukanlah belajar yang kaku, verbalis, dan mementingkan materi. Dunia pendidikan sekarang adalah tempat dimana orang harus mengerahkan seluruh kekuatan, pikiran, dan kemampuan yang memerlukan kreativitas tinggi. Pembelajaran yang diperlukan saat ini adalah pembelajaran yang luwes, penuh kegembiraan, bekerjasama, mementingkan aktivitas, dan kontekstual. Kegiatan belajar sebagai kegiatan yang penting selama hidup manusia, menjadi pengalaman yang menyenangkan, mengasyikkan, dan merangsang pikiran. Berbagai cara dapat ditempuh oleh guru agar pembelajaran menarik dan kontektual, tidak membosankan, mudah dipahami, dan mudah dimengerti siswa sehingga pembelajaran tidak mudah dilupakan. Salah satu cara yang dapat ditempuh antara lain dengan 
menampilkan alat peraga sebagai media pembelajaran dalam mengajar.

Kondisi yang sama terdapat di kelas VII A SMP Negeri 2 Ngemplak. Dalam pembelajaran IPS siswa masih menghapal, kurang mengembangkan kemampuan berpikir, kurang mengkontruksi pengetahuan yang diperoleh masih berdasarkan informasi dari guru. Siswa belum dibiasakan menemukan sendiri pengetahuan melalui pengalaman langsung, akibatnya pengetahuan menjadi tidak bermakna dan cepat terlupakan. Kondisi siswa tersebut berpengaruh terhadap hasil belajar, sebagai bukti dari hasil ulangan yang dilakukan sebelumnya di kelas VII A kurang memuaskan, dari 31 siswa yang mendapatkan hasil sesuai dan di atas KKM (Kriteria Ketuntasan Minimal) sebesar 75 hanya 8 siswa sedangkan 23 siswa di bawah KKM. Secara klasikal ketuntasan belajar hanya 25,8 \% dari yang ditetapkan sebesar 85 $\%$, belum sesuai yang diharapkan.

Dari permasalahan yang ada di kelas VII A SMPN 2 Ngemplak dalam proses pembelajaran IPS, maka guru terdorong untuk mengatasi hasil belajar siswa yang rendah tersebut dengan menggunakan media maket bubur kertas terutama untuk materi Vulkanisme. Alasan penggunaan media maket bubur kertas selain siswa dapat mengetahui proses terbentuknya gunung secara nyata, kontekstual, praktis, juga bahan-bahan yang digunakan sangat murah, bahkan sudah tidak digunakan lagi. Penggunaan media tersebut sangat penting ketika seorang guru mengajar di dalam kelas (class room teaching). Pengunaan media pembelajaran secara tepat dapat membantu peserta didik untuk memahami materi palajaran agar materi yang dipelajari. Seperti disampaikan oleh Pupuh (2007: 65-66) yang berpendapat bahwa:

Media memiliki andil untuk menjelaskan hal-hal yang abstrak dan menunjukkan hal-hal yang tersembunyi. Ketidakjelasan 
atau kerumitan bahan ajar dapat dibantu dengan menghadirkan media sebagai perantara. Bahkan dalam hal-hal tertentu media dapat mewakili kekurangan guru dalam mengkomunikasikan materi pelajaran. Tetapi penggunaannya hendaknya sejalan dengan esensi tujuan pengajaran yang telah dirumuskan.

Apabila permasalahan hasil belajar mata pelajaran IPS di SMP Negeri 2 Ngemplak tersebut dibiarkan maka akan berdampak pada rendahnya kualitas proses belajar IPS selanjutnya dan rendahnya mutu pendidikan. Dalam penelitian ini masalah dirumuskan sebagai berikut: Bagaimana meningkatkan hasil belajar IPS materi Vulkanisme melalui media maket bubur kertas siswa kelas VII A SMP Negeri 2 Ngemplak semester 1 tahun pelajaran 2013/2014? Berdasarkan rumusan masalah yang ditetapkan maka tujuan penelitian untuk mengetahui peningkatan hasil belajar IPS materi Vulkanisme melalui media maket bubur kertas siswa kelas VII A SMP Negeri 2 Ngemplak semester 1 tahun pelajaran 2013/2014.

\section{Hasil Belajar}

Langkah terakhir dari proses pembelajaran adalah melaksanakan evaluasi atau penilaian terhadap sejauh mana proses pembelajaran dapat mencapai tujuan. Evaluasi atau penilaian merupakan salah satu komponen sistem pembelajaran. Pengembangan alat evaluasi merupakan bagian integral dalam pengembangan sistem pembelajaran. Oleh karena fungsi evaluasi adalah untuk mengetahui apakah tujuan yang dirumuskan dapat tercapai, evaluasi merupakan salah satu faktor penting dalam proses pembelajaran (Sumiati dan Asra, 2009: 200). Diperkuat Sunarti dan Selly (2012: 1) yang mengemukakan bahwa penilaian merupakan rangkaian kegiatan untuk memperoleh, menganalisis, dan menafsirkan data tentang proses dan hasil belajar peserta didik yang dilakukan secara sistematis dan berkesinambungan, 
sehingga menjadi informasi yang bermakna dalam mengambil keputusan.

Berkaitan dengan tujuan penilaian hasil belajar Zainal Aqib (2010: 69) mengemukakan bahwa tujuan evaluasi hasil belajar adalah memberikan informasi yang berkenaan dengan kemajuan siswa, pembinaan kegiatan belajar, menerapkan kemampuan dan kesulitan, untuk mendorong motivasi belajar, membantu perkembangan tingkah laku, dan membimbing siswa untuk memilih sekolah atau jabatan/pekerjaan. Evaluasi atau penilaian untuk mengetahui hasil belajar yang merupakan aktivitas yang sangat penting dalam proses pendidikan. Semua proses pembelajaran di lembaga pendidikan formal pada akhirnya akan bermuara pada hasil belajar yang diwujudkan secara kuantitatif berupa nilai.

Berdasarkan pernyataan yang telah diuraikan di atas, dapat disimpulkan bahwa hasil belajar adalah hasil yang diperoleh dari proses pembelajaran, hasil belajar yang telah diukur atau dinilai dinamakan prestasi belajar. Pencapaian prestasi belajar individu sangat dipengaruhi oleh beberapa faktor, seperti kemampuan atau daya intelektual, lingkungan, dan faktor-faktor lainnya. Pengaruh dari berbagai faktor ini mengarahkan individu yang sedang belajar untuk bertindak sesuai dengan kemampuan yang mereka miliki dalam menjawab dan memecahkan permasalahan yang mereka hadapi dalam proses pembelajaran.

\section{Hakekat IPS}

Ilmu Pengetahuan Sosial (IPS) berasal dari Amerika dengan nama Social Studie. National Council for Social (NCSS) (Supardi, 2011: 182) bahwa IPS atau Social Studies sebagai berikut:

"Social studies is the integrated study of the social sciences and humanities to promote civic competence. Within the school 
program, discipline as anthropology, archaeology, psychology, economics, geography, history, law, philosophy, political science, psychology, religion, and sociology, as well appropriate content from the humanities, mathematics, and the natural sciences."

Sementara Djahiri dan Ma'mun (Rudy Gunawan, 2011: 17) berpendapat bahwa "IPS atau studi sosial konsep-konsepnya merupakan konsep pilihan dari berbagai ilmu lalu dipadukan dan diolah secara didaktis-pedagogis sesuai dengan tingkat perkembangan siswa".

Tujuan dari pendidikan IPS sebenarnya erat kaitanya dengan pendidikan karakter. Seperti menumbuhkan rasa peduli dalam memahami lingkungan sekitar, mengembangkan pengetahuan, pemahaman, dan kemampuan analisis terhadap kondisi sosial masyarakat dalam memasuki kehidupan bermasyarakat yang dinamis. Sehingga dengan pembelajaran IPS akan dapat menumbuhkan manusia yang berpikir kritis, logis, analistis, sistematis, dan kreatif dan peka terhadap lingkungan.

Pembelajaran IPS berkaitan dengan kehidupan manusia yang melibatkan segala tingkah laku dan kebutuhannya. IPS berkaitan dengan cara manusia memenuhi kebutuhannya, baik kebutuhan untuk memenuhi materi, budaya, dan kejiwaannya, memanfaatkan sumber daya yang ada di permukaan bumi, mengatur kesejahteraan dan pemerintahan maupun kebutuhan lainnya dalam rangka mempertahankan kehidupan masyarakat manusia.

Dapat ditarik kesimpulan bahwa pembelajaran IPS sangat penting untuk diberikan karena berkaitan dengan kemampuan siswa dalam menyelesaikan masalah-masalah yang terjadi dalam masyarakat secara holistik, terutama dalam menghadapi tantangan global sesuai perkembangan jaman. 


\section{Media Maket Bubur Kertas}

Media dalam pembelajaran dapat diterjemahkan sebagai alat peraga untuk lebih memperjelas maksud dari suatu yang dibicarakan. Menurut Pupuh (2007: 65), Media adalah perantara atau pengantar pesan dari pengirim pesan kepada penerima pesan. Media apabila dipahami secara garis besar adalah manusia, materi atau kejadian yang membangun suatu kondisi yang membuat siswa mampu memperoleh pengetahuan, keterampilan atau sikap.

Dalam pembelajaran sering terjadi salah komunikasi yang disebabkan materi terlalu abstrak bagi peserta didik. Untuk mengurangi tingkat kesalahan komunikasi maka digunakan media belajar/alat peraga. Alat peraga dalam mengajar memegang peranan penting sebagai alat bantu untuk menciptakan proses belajar mengajar yang efektif dan inovatif. Banyak media yang dapat dimanfaatkan untuk menunjang pembelajaran, karena itu perlu dirancang dengan baik bukan hanya pembuatan media itu sendiri, tetapi juga mengenai pemanfaatannya (Mukhtar, 2007: 116).

Maket adalah tiruan suatu bentuk yang diperkecil sesuai aslinya. Maket merupakan salah satu media pembelajaran, yang diharapkan dapat meningkatkan hasil belajar siswa terutama materi Vulkanisme. Dengan media pembelajaran maket, siswa diajak ke pembelajaran kontektual. Maket termasuk dalam golongan peta timbul, peta timbul pada dasarnya peta datar yang dibentuk dengan tiga dimensi. Dibuat dari tanah liat atau bubur kertas. Penggunaannya sama dengan peta datar (Nana sudjana, 2011:101).

Keuntungan menggunakan media model, dalam hal ini maket menurut Daryanto (2013: 31), belajar dapat difokuskan pada 
bagian yang penting-penting saja, dapat menunjukkan struktur dalam suatu obyek, siswa memperoleh pengalaman yang kongkrit. Maket dibuat langsung oleh siswa dengan tujuan memudahkan dalam memahami materi yang diterangkan. Selain itu, pembuatan maket dengan menggunakan bubur kertas dengan maksud selain memanfaatkan barang bekas, hemat biaya, mudah dicari dan mudah untuk membuatnya, menumbuhkan enterpreneurship atau kewirausahaan karena bubur kertas dapat dijadikan untuk kerajinan yang memiliki nilai jual.

\section{Metode Penelitian}

Penelitian tindakan kelas ini dilaksanakan di SMPN 2 Ngemplak, Macanan, Bimomartani, Ngemplak, Sleman, Daerah Istimewa Yogyakarta. Penelitian dilaksanakan pada semester 1 tahun pelajaran 2013/2014. Waktu penelitian ini direncanakan lima bulan dimulai dari penulisan proposal, pengamatan kondisi awal, tindakan sampai penulisan laporan. Pelaksanan penelitian pada tanggal 10, 12, 17 September 2013 yang direncanakan tiga siklus tetapi tidak menutup kemungkinan bertambah apabila belum sesuai dengan yang diharapkan.

Penelitian ini mengambail Standar Kompetensi tentang Memahami Lingkungan Kehidupan manusia dan Kompetensi Dasar mendeskripsikan keragaman bentuk muka bumi, proses pembentukan,dan dampaknya terhadap kehidupan. Dalam kompetensi dasar tersebut lebih memfokuskan pada materi Vulkanisme.

Subjek Penelitian ini adalah siswa kelas VII A di SMP N 2 Ngemplak Kabupaten Sleman yang berjumlah 31 orang siswa terdiri dari 14 siswa laki-laki dan 17 siswa perempuan. Pemilihan subjek kelas VII A dikarenakan siswa kelas tersebut memiliki permasalahan dalam hasil belajar mata pelajaran IPS. 
Berdasarkan hasil ulangan yang dilakukan menunjukkan persentase siswa yang belum tuntas masih 25,8 belum sesuai KKM yang ditetapkan.

Penelitian ini merupakan Penelitian Tindakan Kelas (Classroom Action Research) yang bertujuan untuk meningkatkan hasil belajar IPS melalui media maket bubur kertas. Penelitian Tindakan Kelas merupakan upaya guru untuk memperbaiki keadaan yang kurang memuaskan dan meningkatkan mutu pembelajaran di kelas.

Penelitian ini menggunakan rancangan penelitian tindakan kelas (PTK) dengan acuan model siklus PTK yang dikembangkan oleh Kemmis \& Taggart yang terdiri dari perencanaan, tindakan, pengamatan dan refleksi. Penelitian dimulai dari pengamatan awal terhadap proses pembelajaran IPS kelas VII A. Selanjutnya peneliti merancang konsep pemecahan masalah melalui pemanfaatan media maket bubur kertas. Penelitian ini di rancang menjadi beberapa siklus sampai siklus ke-n. Jika tindakan telah sesuai dengan target keberhasilan yang telah ditetapkan maka tidak dilanjutkan lagi pada siklus berikutnya. Sedangkan pada setiap siklus terdiri dari beberapa pertemuan tatap muka dengan alokasi waktu $2 \times 40$ menit. Pengumpulan data dalam penelitian ini menggunakan beberapa metode yaitu observasi, tes, dokumentasi, dan catatan lapangan.

Metode analisis data yang digunakan dalam penelitian ini adalah analisa deskriptif kuantitatif. Untuk mencapai keabsahan data maka dilakukan validasi data, dalam penelitian ini digunakan metode triangulasi dengan cara memanfaatkan berbagai sumber. Metode pengumpulan data yang digunakandalam penelitian ini dengan menggunakan observasi, dokumentasi, dan catatan lapangan sehingga dapat dipertanggungjawabkan hasilnya. 
Penelitian ini untuk mengukur hasil belajar diperlukan validasi isi dari intrumen butir-butir/item-item tes. Sebelum alat ukur atau instrumen diujicobakan kepada responden, item-item tes yang sudah disusun berdasarkan kisi-kisi tes hasil belajar dengan materi Vulkanisme terlebih dahulu dikonsultasikan kepada para pakar untuk dilakukan penilaian.

\section{Hasil Penelitian}

Peneliti telah mengadakan pengamatan awal dengan mengidentifikasi masalah yang dihadapi guru selama proses pembelajaran IPS. Berdasarkan permasalahan yang diperoleh dijadikan sebagai pedoman untuk merencanakan, memodifikasi pemecahan masalahan yang ditemukan sehingga pembelajaran menjadi lebih efektif dan efisien.

Hasil pengamatan pada kondisi awal terutama terhadap hasil belajar IPS diperoleh data $25.8 \%$ siswa yang tuntas dalam pelajaran IPS sesuai dengan KKM mata pelajaran IPS di SMP Negeri 2 Ngemplak yang ditetapkan sebesar 75 terdapat $74,2 \%$ siswa belum tuntas belajar sehingga termasuk kategori kriteria kurang. Secara klasikal belum memenuhi kriteria ketuntasan yang ditetapkan sebesar 85\%. Lebih jelasnya perhatikan tabel berikut:

Tabel 1. Analisis Hasil Belajar Prasiklus

\begin{tabular}{|l|l|l|l|}
\hline \multicolumn{2}{|l|}{ Uraian } & $\begin{array}{l}\text { Tidak } \\
\text { tuntas }\end{array}$ & Tuntas \\
\hline $\begin{array}{l}\text { Presentase } \\
\text { ketuntasan }\end{array}$ & & 74,2 & 25,8 \\
\hline $\begin{array}{l}\text { Nilai Rata- } \\
\text { rata }\end{array}$ & 71 & & \\
\hline $\begin{array}{l}\text { Nilai } \\
\text { Tertinggi }\end{array}$ & 85 & & \\
\hline $\begin{array}{l}\text { Nilai } \\
\text { Terendah }\end{array}$ & 55 & & \\
\hline
\end{tabular}

Sumber: Hasil nilai Prasiklus 


\section{Pembahasan}

Mengingat permasalahan yang dihadapi, maka perlu adanya upaya meningkatkan hasil belajar siswa dalam pembelajaran IPS. Untuk mengatasi hal tersebut, perlu digunakan strategi yang mengarah pada pembelajaran yang aktif, kreatif, inovatif, efektif, dan menyenangkan. Salah satu strategi pembelajaran yang cocok untuk memecahkan permasalahan di atas adalah memanfaatkan media maket bubur kertas pada materi Vulkanisme.

a. Hasil Siklus I

Siklus I dilaksanakan pada tanggal 10 September 2013 dimana satu pertemuannya 2 Jam Pelajaran (JP) atau $2 \times 40$ menit. Siklus I dilaksanakan dengan Standar Kompetensi dan Kompetensi Dasar yang ada di semester ganjil dengan materi Vulkanisme. Selama pelaksanaan tindakan, Guru mata pelajaran IPS sebagai peneliti sekaligus pengajar dibantu Observer yang bertugas mengamati serta mencatat pelaksanaan tindakan pada proses pembelajaran.

Hasil belajar pada siklus I secara klasikal untuk siswa yang sudah tuntas atau nilai di atas KKM pada pretes sebesar 6,5\% sedangkan pada postes sebesar 19,4\% dengan kriteria kurang, terjadi peningkatan $12,9 \%$. Ketuntasan secara klasikal Lebih jelasnya perhatikan tabel.

Tabel 2 Analisis Hasil Belajar Siswa Siklus I

\begin{tabular}{|c|c|c|c|}
\hline Uraian & Pretes & Postes & Keterangan \\
\hline Persentase ketuntasan & $6,5 \%$ & $19,4 \%$ & \multirow{4}{*}{$\begin{array}{c}\text { Peningkatan } \\
\text { ketuntasan belajar } \\
\text { sebesar } 12,9 \%\end{array}$} \\
\hline Nilai Rata-rata & 50 & 66 & \\
\hline Nilai Tertinggi & 80 & 80 & \\
\hline Nilai Terendah & 20 & 50 & \\
\hline
\end{tabular}

Sumber: Hasil belajar siklus I

Berdasarkan hasil observasi kegiatan pembelajaran dan catatan lapangan setelah pelaksanaan pembelajaran pada siklus I, 
dapat diperoleh kesimpulan bahwa pelaksanaan pembelajaran IPS dengan maket bubur kertas belum optimal. Pada awal sampai akhir proses pembelajaran, perhatian siswa belum sepenuhnya terpusat pada materi pelajaran. Siswa masih belum paham dengan langkah-langkah membuat maket. Pada saat membuat maket, siswa cenderung masih bermain-main sehingga pembelajan belum optimal.Kelemahan yang terjadi pada siklus I dijadikan acuan dalam perencanaan dan akan diperbaiki pada siklus II nanti. Adapun kelemahan pada siklus I dapat direfleksi sebagai berikut:

1) Ada satu kelompok yang tidak membawa lem kanji

2) ada satu kelompok yang belum meminjam buku referensi diperpustakaan.

3) Karena keinginan untuk segera membuat maket sehingga petunjuk kerja tidak dibaca sehingga terjadi kesalahan dalam membuat.

4) Pembagian kerja kelompok belum jelas sehingga semuannya berkeinginan untuk ikut membuat sehingga lembar kegiatan siswa terlambat mengerjakan.

5) Dalam pekerjaan kelompok dibagi dua , ada yang membuat maket dan ada yang mengerjakan soal. Mereka asyik dengan pekerjaan masing-masing dan tidak menginformasikan satu sama lain sehingga yang mengerjakan maket tidak tahu jawaban pada lembar kerja siswa dan yang mengerjakan soal tidak tahu cara membuat maket.

6) Beberapa anak masih cenderung untuk bermain dan mengganggu teman yang lain

7) Pemahaman siswa terkait materi Vulkanisme masih kurang. Hal ini dapat diketahui pada saat siswa presentasi hasil kerja kelompok, penyajinya masih sering berhenti untuk membaca buku karena lupa. 
8) Secara klasikal untuk siswa yang sudah tuntas atau nilai di atas KKM pada pretes sebesar 6,5\% sedangkan pada postes sebesar 19,4\% dengan kriteria kurang. Ketuntasan secara klasikal belum berhasil sesuai ketuntasan yang ditetapkan sebesar $85 \%$.

Refleksi berikutnya untuk memperbaiki kelemahan pada siklus I yang akan diperbaiki pada siklus yang kedua dengan cara:

1) Penjelasan materi Vulkanisme lebih ditambah.

2) Mengingatkan bahan-bahan yang harus dibawa pada pertemuan berikutnya serta perlengkapan lain.

3) Pengarahan lebih optimal terutama dalam memahami petunjuk kerja sehingga tidak terjadi kesalahan dalam membuat.

4) Mengingatkan dalam kerja kelompok adanya pembagian kerja yang jelas sehingga semua tidak ikut membuat dan adanya saling kerjasama atara yang membuat dengan yang mengerjakan lembar kerja siswa.

5) Memotivasi siswa yang mewakili kelompoknya untuk presentasi sehingga lebih siap dan menguasai materi.

Dapat disimpulkan dari kelemahan-kelemahan baik hasil kemampuan proses maupun hasil belajar pada siklus I pembelajaran masih kurang maksimal yang akan dijadikan acuan dalam perbaikan pada siklus II.

b. Hasil Siklus II

Siklus II dilaksanakan pada12 September 2013 dengan 2 Jam Pelajaran (JP) atau $2 \times 40$ menit. Siklus II merupakan perbaikan dari siklus I, yang dilaksanakan dengan maket bubur kertas pada materi Vulkanisme. Selama pelaksanaan tindakan, Guru mata pelajaran IPS sebagai peneliti sekaligus pengajar dibantu Observer yang bertugas mengamati serta mencatat pelaksanaan tindakan pada proses pembelajaran. 
Analisis hasil belajar siswa pada siklus IIdiperoleh dari hasil tes yang dilakukan.baik pretes maupun postes. Secara klasikal untuk siswa yang sudah tuntas atau mendapatkan nilai di atas KKM pada pretes sebesar $45 \%$ dengan kategori kurang sedangkan pada postes sebesar $71 \%$ dengan kategori baik, hasil tersebut menunjukkan terjadi peningkatan 26\%. Ketuntasan secara klasikal belum berhasil sesuai ketuntasan yang ditetapkan sebesar $85 \%$.

Tabel 3 Analisis Hasil Belajar Siswa Siklus II

\begin{tabular}{|c|c|c|c|}
\hline Uraian & Pretes & Postes & Keterangan \\
\hline Persentase ketuntasan & $45 \%$ & $71 \%$ & \multirow{4}{*}{$\begin{array}{l}\text { Peningkatan } \\
\text { ketuntasan belajar } \\
\text { sebesar } 26 \%\end{array}$} \\
\hline Nilai Rata-rata & 72 & 79 & \\
\hline Nilai Tertinggi & 90 & 100 & \\
\hline Nilai Terendah & 50 & 60 & \\
\hline
\end{tabular}

Sumber: Hasil belajar siswa siklus II

Berdasarkan hasil observasi kegiatan pembelajaran dan catatan lapangan setelah pelaksanaan pembelajaran pada siklus II, dapat diperoleh kesimpulan bahwa pelaksanaan pembelajaran IPS dengan maket bubur kertas sudah sesuai yang diharapkan. Pada awal sampai akhir proses pembelajaran, perhatian siswa sudah lebih terpusat pada materi pelajaran. Siswa sudah paham dengan langkah-langkah yang harus dilaksanakan dalam mewarnai maket. Meskipun demikian masih terdapat kelemahan yang terjadi pada siklus II yang dijadikan acuan dalam perencanaan dan akan diperbaiki pada siklus III.

c. Hasil Siklus III

Siklus III dilaksanakan pada 17 September 2013 dengan waktu 2 x 40 menit. Siklus III merupakan perbaikan dari siklus II, yang dilaksanakan dengan maket bubur kertas dengan materi Vulkanisme. Pada siklus III karena merupakan berbaikan dari siklus I dan II sehingga berjalan lebih baik. 
Pada siklus III berdasarkan hasil pengamatan peneliti maupun oleh kolaborator dengan menggunakan lembar observasi pengamatan guru dan siswa. Hasil pengamatan terhadap guru yaitu gurumempersiapkan pembelajaran dengan baik dan sudah maksimal memberikan penjelasan kepada siswa. Guru memberikan penghargaan terhadap siswa maupun kelompok yang aktif sehingga pembelajaran menjadi lebih aktif dan kondusif. Dapat dikatakan bahwa guru pada siklus IIIsudah maksimal dalam menjalankan perannya sebagai fasilitator dan motivator.

Pengamatan terhadap siswa, hampir semua siswa aktif. Di tiap kelompok telah mempersiapkan bahan-bahan untuk simulasi erupsi dengan baik. Siswa lebih percaya diri dalam pembelajaran maupun dalam menggerjakan evaluasi pembelajaran. Analisis hasil belajar pada siklus III secara klasikaluntuk siswa yang sudah tuntas atau nilai di atas KKM pada pretes sebesar 80,6\% dengan kategori baik sedangkan pada postes sebesar 90\% dengan kategori baik sekali, terjadi peningkatan 9,4\% . Ketuntasan secara klasikal sudah berhasil sesuai ketuntasan yang ditetapkan sebesar 85\%. Lebih jelasnya perhatikan tabel berikut:

Tabel 4 Analisis Hasil Belajar Siswa Siklus III

\begin{tabular}{|c|c|c|c|}
\hline Uraian & Pretes & Postes & Keterangan \\
\hline Persentase & & & \multirow{5}{*}{$\begin{array}{c}\text { Peningkatan } \\
\text { ketuntasan belajar } \\
\text { sebesar } 9,4 \%\end{array}$} \\
\hline ketuntasan & $80,6 \%$ & $90 \%$ & \\
\hline Nilai Rata-rata & 84 & 88 & \\
\hline Nilai Tertinggi & 100 & 100 & \\
\hline Nilai Terendah & 60 & 70 & \\
\hline
\end{tabular}

Sumber: hasil belajar siswa siklus III

Berdasarkan hasil observasi kegiatan pembelajaran dan catatan lapangan setelah pelaksanaan pembelajaran pada siklus III diperoleh kesimpulan bahwa pelaksanaan pembelajaran IPS dengan maket bubur kertassudah sesuai yang diharapkan bahkan 
lebih. Respon siswa dalam pembelajaran dengan maket bubur kertas sangat baik. Siswa terlihat senang dan sangat bersemangat. Pembelajaran menjadi sangat menyenangkan dan kondusif. Antusias siswa dalam mengikuti proses pembelajaran sudah terlihat dalam setiap langkah-langkah pembelajaran serta banyak dari siswa yang sudah fokus dengan pembelajaran yang dilakukan. Kekurangan pada siklus-siklus sebelumnya sudah mengalami perbaikan sehingga proses pembelajaran menjadi lebih baik dari sebelumnya.

Pada siklus III persentase siswa yang mencapai nilai di atas KKM yang ditetapkan sebesar 75 yaitu 27 siswa atau sebesar 90\%. Pada siklus ini sudah mencapai kriteria keberhasilan yang telah ditetapkan yaitu $85 \%$ bahkan melebihi target yang ditetapkan. Meskipun demikian masih ada beberapa kendala yang ditemui pada siklus III antara lain kondisi kelas menjadi labih kotor karena terkena pewarna. Meskipun ada kendala tersebut tetapi tidak berpengaruh pada proses pembelajaran dan dapat diatasi.

Dapat disimpulkan dari hasil yang diperoleh pada siklus III sudah sesuai dengan indikator yang ditetapkan, maka terbukti bahwa media maket bubur kerta mampu meningkatkan hasil belajar.

Penelitian ini merupakan jenis Penelitian Tindakan Kelas (ClassroomAction Research). Penelitian tindakan kelas ini dilaksanakan di SMP Negeri 2 Ngemplak yang dilakukan sebanyak tiga siklus. Penelitian ini bertujuan untuk meningkatkan hasil belajar IPS materi Vulkanisme melalui media maket bubur kertas siswa kelas VII A SMPN 2 Ngemplak semester 1 tahun pelajaran $2013 / 2014$.

Analisis hasil belajar pada pra siklus, siklus I, siklus II, dan siklus III menunjukkan bahwa pembelajaran dengan media maket 
dapat meningkatkan hasil belajar siswa dalam pembelajaran IPS di SMP Negeri 2 Ngemplak. Hal ini didukung dengan data hasil belajar siswa yang meningkat tiap siklusnya sampai berhasil mencapai kriteria keberhasilan yang telah ditetapkan pada siklus III.

Dari hasil analisis hasil belajar siswa yang dilaksanakan menunjukkan adanya peningkatan, pada prasiklus hasil rata-rata persentase sebesar 25. 8\% yang tuntas dengan kategori kurang, siklus I persentase ketuntasan belajar dari 6,5\% pada pretes dan $19,4 \%$ pada postes dengan kategori kurang, jadi mengalami peningkatan $12,9 \%$. Siklus II persentase ketuntasan belajar dari $45 \%$ dengan kategori kurang menjadi $71 \%$ dengan kategori baik jadi meningkat $26 \%$. Untuk siklus yang ketiga hasil pretes $80,6 \%$ dengan kategori baik menjadi 90\% dengan kategori baik sekali, jadi mengalami peningkatan 9,4\%. Hasil tersebut sudah sesuai dengan kriteria ketuntasan yang diharapkan bahkan melebihi target sebesar $85 \%$, hal ini menunjukkan pembelajaran IPS materi Vulkanisme melalui maket bubur kertas dapat meningkatkan hasil belajar. Lebih jelasnya terlihat pada tabel di bawah ini

Tabel 5 Analisis Hasil Belajar Prasiklus, Siklus I, Siklus II, dan Siklus III

\begin{tabular}{|c|c|c|c|c|c|c|c|c|c|c|c|}
\hline \multirow{2}{*}{ Uraian } & \multirow{2}{*}{ Hasil } & \multirow{2}{*}{$\begin{array}{l}\text { Pra } \\
\text { siklus }\end{array}$} & \multicolumn{2}{|c|}{ Siklus I } & \multirow{2}{*}{ Ket } & \multicolumn{2}{|c|}{ Siklus II } & \multirow{2}{*}{$\begin{array}{l}\text { Keter } \\
\text { angan }\end{array}$} & \multicolumn{2}{|c|}{ Siklus III } & \multirow{2}{*}{ Ket } \\
\hline & & & $\begin{array}{l}\text { Pre } \\
\text { tes }\end{array}$ & $\begin{array}{l}\text { Pos } \\
\text { tes }\end{array}$ & & $\begin{array}{l}\text { Pre } \\
\text { tes }\end{array}$ & $\begin{array}{l}\text { Pos } \\
\text { tes }\end{array}$ & & $\begin{array}{l}\text { Pre } \\
\text { tes }\end{array}$ & $\begin{array}{l}\text { Pos } \\
\text { Tes }\end{array}$ & \\
\hline $\begin{array}{l}\text { Persentase } \\
\text { ketuntasan }\end{array}$ & 22,8 & \multirow{4}{*}{$\begin{array}{l}\text { Ketun } \\
\text { tasan } \\
\text { belaja } \\
\mathrm{r} \\
\text { sebes } \\
\text { ar } \\
25,8 \%\end{array}$} & $6,5 \%$ & $19,4 \%$ & \multirow{4}{*}{$\begin{array}{c}\text { Pening } \\
\text { katan } \\
\text { ketunta } \\
\text { san } \\
\text { belajar } \\
\text { sebesar } \\
12,9 \%\end{array}$} & $45 \%$ & $\begin{array}{l}71 \\
\%\end{array}$ & \multirow{4}{*}{$\begin{array}{c}\text { Penin } \\
\text { gkata } \\
\mathrm{n} \\
\text { ketun } \\
\text { tasan } \\
\text { belaja } \\
\mathrm{r} \\
\text { sebes } \\
\text { ar } \\
26 \%\end{array}$} & $\begin{array}{c}80,6 \\
\%\end{array}$ & $90 \%$ & \multirow{4}{*}{$\begin{array}{l}\text { Pening } \\
\text { katan } \\
\text { ketunta } \\
\text { san } \\
\text { belajar } \\
\text { sebesar } \\
9,4 \%\end{array}$} \\
\hline $\begin{array}{l}\text { Nilai Rata- } \\
\text { rata }\end{array}$ & 71 & & 50 & 66 & & 72 & 79 & & 84 & 88 & \\
\hline $\begin{array}{l}\text { Nilai } \\
\text { Tertinggi }\end{array}$ & 85 & & 80 & 80 & & 90 & $\begin{array}{c}10 \\
0\end{array}$ & & 100 & 100 & \\
\hline $\begin{array}{l}\text { Nilai } \\
\text { Terendah }\end{array}$ & 55 & & 20 & 50 & & 50 & 60 & & 60 & 70 & \\
\hline
\end{tabular}

Sumber: Analisis hasil belajar prasiklus, siklus I, siklus II, dan siklus III 


\section{Simpulan}

Media maket bubur kertas dapat meningkatkan hasil belajar IPS materi Vulkanisme siswa kelas VII A SMPN 2 Ngemplak Semester 1 tahun pelajaran 2013/2014. Hal ini dapat dibuktikan dari analisis hasil belajar siswa menunjukkan adanya peningkatan, pada pra-siklus hasil rata-rata persentase kentuntasan belajar secara klasikan sebesar $25.8 \%$, siklus I persentase ketuntasan belajar dari $6,5 \%$ pada pretes menjadi $19,4 \%$ pada postes dengan kategori kurang, mengalami peningkatan 12,9\%. Pada siklus II persentase ketuntasan belajar dari $45 \%$ dengan kategori kurang menjadi $71 \%$ dengan kategori baik jadi meningkat 26\% sedangkan siklus III dari $80,6 \%$ pada pretes dengan kategori baik menjadi 90\% dengan kategori baik sekali jadi mengalami peningkatan sebesar 9,4\% . Hasil tersebut sudah sesuai dengan kriteria ketuntasan yang diharapkan bahkan melebihi target sebesar 85\%. Hal ini menunjukkan pembelajaran IPS pada materi Vulkanisme melalui media maket bubur kertas dapat meningkatkan hasil belajar.

\section{Saran}

Berdasarkan penelitian yang telah dilakukan, maka peneliti mempunyai beberapa saran sebagai berikut:

1. Guru sebaiknya dalam pembelajaran IPS dengan materi Vulkanisme dapat memanfaatkn media maket bubur kertas untuk meningkatkan hasil belajar siswa.

2. Dalam memanfaatkan media pembelajaran dengan menggunakan maket, guru harus mampu memotivasi dan menyusun serta merancang pembelajaran yang menarik sehingga siswa lebih tertarik dalam pembelajaran.

3. Dalam menggunakan media pembelajaran di kelas sebaiknya guru menggunakan media yang benar-benar relevan dan mudah dipahami siswa.

4. Guru harus memotivasi siswa untuk belajar kontekstual antaralain dengan membuat media pembelajaran maket terutama pada materi Vulkanisme meskipun dengan bahan yang sederhana. 
5. Guru berani mengubah paradikma lama dari guru sentris menjadi siswa sentris terutama menggunakan pendekatan CTL sehingga siswa akan lebih jelas dan lebih memahami materi.

6. Guru hendaknya harus aktif menggali kemampuan siswa dengan cara membuat siswa aktif mulai dari merancang sampai mengkomunikasikan hasil.

\section{Daftar Pustaka}

Anwar Kurnia. (2009). IPS Terpadu SMP Kelas VII. Jakarta: Yudistira

Astuti, Wiwin Wiji, dkk. (2012). Pengaruh Motivasi Belajar dan Metode Pembelajaran Terhadap Hasil Belajar IPS Terpadu Kelas VIII PGRI 16 Brongsong Kabupaten Kendal. EEDJ 1 (2) (2012) di unduh tanggal 20September 2013 jam 20.00 WIB dari unfile: / / C:/Users / ASUSPC/Downloads /540-1067-1-SM.pdf.

Daryanto.(2013). Media Pembelajaran. Yogyakarta: Gava Media

Depdiknas. (2006). Kurikulum 2006 Mata Pelajaran Ilmu Pengetahuan Sosial untuk Sekolah Menengah Pertama(SMP)/Madrasah Tsanawiyah (MTs). Jakarta: Direktorat Pendidikan.

Deni Koswara H. (2008). Bagaimana Menjadi Guru Kreatif. Bandung: PT.Pribumi Mekar.

Endang Ekowati, dkk. (2011). Makalah Ilmu Pengetahuan Sosial Terpadu. Malang: PPPPTK PKn dan IPS.

Pupuh Fathurrohman dan M. Sobry Sutikno. (2007). Strategi Belajar Mengajar. Bandung: Reifka Aditama.

Mukhtar dan Martinis Yamin. (2007). 10 Kiat Sukses Mengajar di Kelas. Jakarta: PT.Nimas Multima

Nana Sudjana (2013). Dasar-dasar Proses Belajar Mengajar. Bandung: Sinar Baru Algensindo.

Nana Sudjana \& Ahmad Rivai (2009). Teknologi Pembelajaran. Bandung: Sinar Baru Algensindo.

Algensindo.

(2011). Media Pengajaran. Bandung: Sinar Baru

Rudy Gunawan. (2011). Pendidikan IPS Filosofi, Konsep, dan Aplikasi. Bandung: CV Alfabeta. 
Supardi.(2011). Dasar - Dasar Ilmu Sosial. Yogyakarta: Ombak

Sumiati dan Asra. (2009). Metode Pembelajaran. Bandung: CV. Wacana Prima.

Sunarti dan Selly R. (2012).Penilaian Hasil Belajar untuk SD, SMP, dan SMA. Yogyakarta: Andi Office

Syaiful Bahri Djamarah. (2008). Psikologi Belajar. Jakarta : PT. Rineka Cipta

Zainal Aqib.(2009). Penelitian Tindakan Kelas. Bandung: CV. Yrama Widya. 